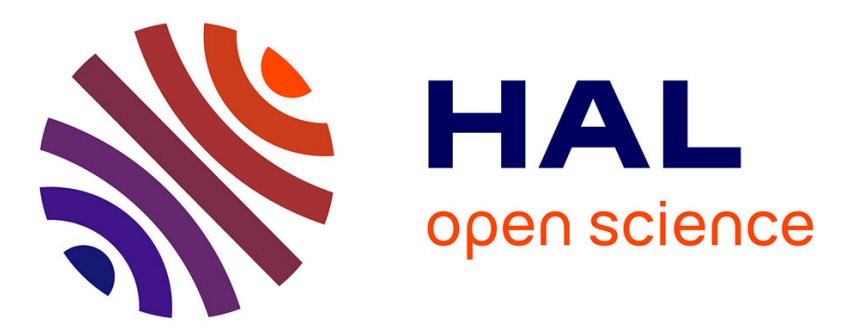

\title{
Innovation and industrial districts: a first approach to the measurement and determinants of the I-district effect
}

\author{
Rafael Boix Domènech, Vittorio Galletto Ciocia
}

\section{To cite this version:}

Rafael Boix Domènech, Vittorio Galletto Ciocia. Innovation and industrial districts: a first approach to the measurement and determinants of the I-district effect. Regional Studies, 2009, 43 (09), pp.11171133. 10.1080/00343400801932342 . hal-00526544

\section{HAL Id: hal-00526544 \\ https://hal.science/hal-00526544}

Submitted on 15 Oct 2010

HAL is a multi-disciplinary open access archive for the deposit and dissemination of scientific research documents, whether they are published or not. The documents may come from teaching and research institutions in France or abroad, or from public or private research centers.
L'archive ouverte pluridisciplinaire $\mathbf{H A L}$, est destinée au dépôt et à la diffusion de documents scientifiques de niveau recherche, publiés ou non, émanant des établissements d'enseignement et de recherche français ou étrangers, des laboratoires publics ou privés. 


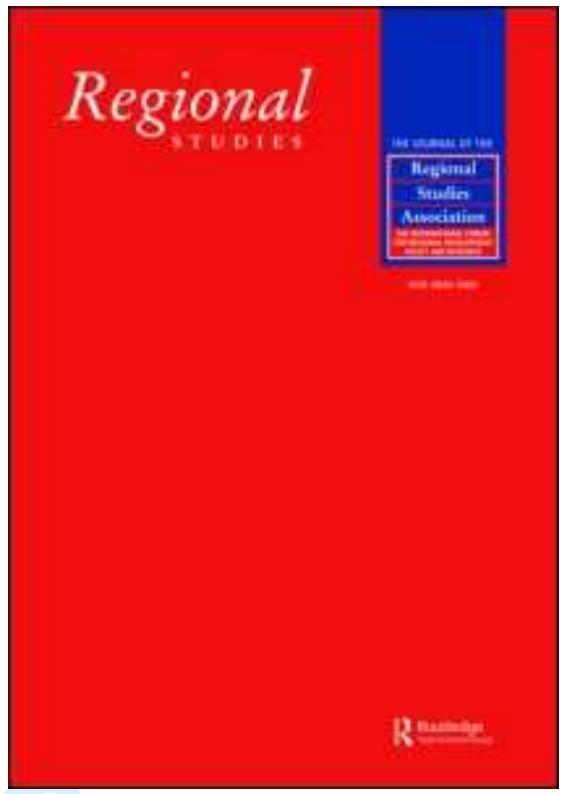

\section{Innovation and industrial districts: a first approach to the measurement and determinants of the I-district effect}

\begin{tabular}{|c|l|}
\hline Journal: & Regional Studies \\
\hline Manuscript ID: & CRES-2007-0190.R1 \\
\hline Manuscript Type: & Main Section \\
\hline JEL codes: & $\begin{array}{l}\text { O14 - Industrialization; Manufacturing; Service Industries; Tech } \\
\text { Choice < O1 - Economic Development < O - Economic } \\
\text { Development, Technological Change, and Growth, O31 - Innovation } \\
\text { and Invention: Processes and Incentives < O3 - Technological } \\
\text { ChangelResearch and Development < O - Economic Development, } \\
\text { Technological Change, and Growth, R12 - Size and Spatial } \\
\text { Distributions of Regional Economic Activity < R1 - General Regional } \\
\text { Economics < R - Urban, Rural, and Regional Economics }\end{array}$ \\
\hline Keywords: & \begin{tabular}{l} 
industrial districts, innovation, external economies, district effect \\
\hline
\end{tabular} \\
\hline
\end{tabular}

\section{SCHOLARONE \\ Manuscripts}


INNOVATION AND INDUSTRIAL DISTRICTS: A FIRST APPROACH TO THE MEASUREMENT AND DETERMINANTS OF THE I-DISTRICT EFFECT

\title{
RAFAEL BOIX and VITTORIO GALLETTO
}

Departament d'Economia Aplicada, Universitat Autònoma de Barcelona, Edifici B, 08193 Cerdanyola del Vallès, Barcelona (Spain)

Emails: rafael.boix@uab.es and vittorio.galletto@uab.es

First received: July 2007

Accepted: November 2007

\begin{abstract}
We analyse an exhaustive database of patents granted in Spain between 2001 and 2006 aggregated in a panel of 806 local labour markets classified by seven typologies of local production systems. Our analysis shows that Marshallian industrial districts generate $30 \%$ of Spanish patents and an innovative output per capita that is $47 \%$ above the national average and $31 \%$ larger than the manufacturing production systems of large firms. The econometric estimates of a fixed effects model confirm the existence of an Innovation-district effect (I-district) and its size. The I-district effect is mainly related to the presence of Marshallian localization economies.
\end{abstract}

Keywords: industrial districts, innovation, external economies, district effect

JEL: O14; O31; R12

"Innovación y distritos industriales: una primera aproximación a la

medición y determinantes del efecto I-distrito". 
Resumen: En la investigación se analiza una exhaustiva base de datos de patentes que entre 2001 y 2006 solicitaron protección en España, agregadas en un panel de 806 $\underline{\text { mercados locales de trabajo clasificados en siete tipologías de sistemas productivos }}$ locales. El análisis muestra que los distritos industriales marshallianos generan el $30 \%$ de las patentes españolas, así como un output innovador per capita $47 \%$ mayor que la media nacional y $31 \%$ mayor que los sistemas productivos manufactureros de gran empresa. Las estimaciones econométricas de un modelo de efectos fijos confirman la $\underline{\text { existencia de un efecto-distrito en innovación (efecto I-distrito) y su dimensión. El }}$ $\underline{\text { efecto I-distrito se asocia principalmente a la presencia de economías de localización }}$ marshallianas.

Keywords are: distritos industriales, innovación, economías externas, efecto distrito

INNOVATION ET DISTRICTS INDUSTRIELS : UNE PREMIERE APPROCHE DE LA MESURE ET DES DETERMINANTS DES EFFETS DES DISTRICTS D'INNOVATION -

\section{RAFAEL BOIX et VITTORIO GALLETTO}

Résumé : Nous analysons une base de données exhaustive de brevets délivrés en Espagne entre 2001 et 2006 dans un échantillon de 806 marchés locaux de l'emploi classés en sept typologies de systèmes locaux de production. Notre analyse montre que les districts industriels de type Marshall génèrent $30 \%$ des brevets espagnols et affichent une performance innovatrice par tête supérieure de $47 \%$ à la moyenne nationale et supérieure de $31 \%$ aux systèmes de production manufacturière des grandes entreprises. Les estimations économétriques d'un modèle d'effet fixe confirment l'existence d'un effet "district d'innovation" et de son importance. L'effet "district 
$\underline{\text { d'innovation" est lié, pour l'essentiel, à la présence d'économie de localisation de type }}$ Marshall.

Mots-clés : districts industriels, innovation, économies extérieures, effet de district.

JEL : O14; O31; R12

Innovation und Industriebezirke: ein erster Ansatz für die Messung und die Determinanten des I-Distrikt-Effekts

RAFAEL BOIX and VITTORIO GALLETTO

Abstract.

Wir analysieren eine umfangreiche Datenbank mit zwischen 2001 und 2006 in Spanien erteilten Patenten, die in einem Panel von 806 lokalen Arbeitsmärkten zusammengefasst und nach sieben Typologien lokaler Produktionssysteme klassifiziert werden. Unsere Analyse zeigt, dass Marshallsche Industriedistrikte $30 \%$ der spanischen Patente und eine innovative Pro-Kopf-Leistung hervorbringen, die um 47\% über dem Landesdurchschnitt liegt und $31 \%$ höher ausfällt aus die Produktionssysteme von Großfirmen. Die ökonometrischen Schätzungen eines Festeffekt-Modells bestätigen die Existenz eines Innovationsdistriktseffekts (I-Distrikt) sowie dessen Größe. Der I-Distrikt-Effekt bezieht sich in erster Linie auf die Präsenz von Marshallschen Lokalisationswirtschaften.

Keywords:

$\underline{\text { Industriebezirke }}$

Innovation

Externe Ökonomien

Distrikteffekt

JEL: O14; O31; R12 


\section{INTRODUCTION}

A large body of Economic Theory attributes a central role to the technological innovations stemming from in-house investments made by large firms in $R \& D$, high levels of educated human capital and large public research infrastructures such as universities. However, the complexity of the innovation process and the multiplicity of ways to innovate can make innovations the outcome of non programmed mechanisms and interaction between productive units located in specific environments. During the course of research of the spatial impacts of universities in Spain, we observed the extraordinary intensity of patent generation in Spanish industrial districts in relation to large-firm manufacturing and service local production systems. Local development theories, and in particular Marshall-Becattini's paradigm of the industrial district provided a "normal" framework to explore the causes of this differential. In this paradigm, the unit of analysis is displaced from the firm or the sector to the territory.

Our intention is not to validate or to subject to falsification the theory of the industrial district or a part of this theory. The main question is why Spanish Marshallian industrial districts show higher rates of innovation per capita than the country's other local production systems (LPS). Departing from the literature on industrial districts, we can focus on three hypotheses, representing three complementary approaches to the industrial district. Following BAGNASCO and TRIGILIA (1984), we can centre on the interaction between market, institutions and policy. Following BRUSCO (1975; 1991), we can focus on a network of small and medium enterprises (SME) characterized by heterogeneous production functions which result in higher rates of technical efficiency (static and dynamic). Finally, following MARSHALL (1890) and BECATTINI (2001), the external economies are at the basis of the system of innovation in industrial districts. 
Although the three approaches provide suggestive and complementary explanations, we will focus on the mechanism that interests us most: the original Marshall - Becattini explanation relying on external economies. Our hypothesis is that higher rates of innovation per capita of Spanish industrial districts are explained by external economies. The objective is to quantify the differential effect of the industrial district on innovation (the I-district effect) and to test whether this effect is explained by external economies.

Given the importance of innovation for competitiveness and the arguments that present industrial districts as a model of mature industries based on costs, the results we present can help throw some light on some points related to this issue. Besides transferring the measurement of the "district effect" to innovation, the research introduces certain contributions such as the use of exhaustive databases and the division of the country into seven types of LPS so that the differential effects are compared not only with the national mean but also with the manufacturing LPS of large firms, large metropolitan areas, service LPS, etc.

The paper is structured as follows. The second section introduces the theoretical framework relating industrial districts, innovation and the district effect. The third section presents the typology of LPS and the first evidence of the I-district effect. The fourth section introduces a modification of Griliches' empirical model in order to measure the I-district effect and its causes, and presents the results of the econometric estimates. The fifth section presents the conclusions.

\section{INDUSTRIAL DISTRICTS, INNOVATION AND THE "DISTRICT EFFECT”}

\subsection{Industrial districts}


MARSHALL (1890) documented the existence of a form of organization of production based on the concentration, in some districts of English industrial cities, of people and SME's specialized in the different stages of a production process. In these "industrial districts", internal scale economies were substituted by external economies related to the existence of qualified workers, specialized suppliers and an informal system of knowledge diffusion. The figure of the Marshallian industrial district was recovered by BECATTINI (1975) to explain the success of the specialized local production systems of SME in the Italian region of Tuscany at the same time that the large-firm productive model of Turin and Milan was at serious crisis. BECATTINI (1990) transferred the unit of analysis from the "firm" or the "sector" to the "industrial district", a "social and territorial entity that is characterized by the active presence of both a community of people and a group of enterprises in a natural and historically determined area". From the late 1970s, the key elements of Marshallian industrial district theory have been addressed by Italian scholars (BECATTINI, 1990; BELLANDI, 2002; BRUSCO 1991; DEI OTTATI, 2002; LAZZERETTI and STORAI, 2003; SFORZI, 1989) and international literature (HARRISON, 1992; OKAMOTO, 2001; PIORE and SABLE, 1984; SENGENBERGER and PYKE, 1992).

The most particular features of the industrial district are the "community" of people who live and work in the same locality, and the concentration of many small firms and workers specialized in the different phases of the same production process (filiere). Although small firms do not benefit from large scale economies as big firms do, the social organisation of the production into specialized localities produces external localization economies, which depend on conditions that are external to the firm and 
internal to the location. These advantages lead to reductions in costs and higher levels of productive efficiency producing the so-called "district effect".

\subsection{Industrial districts and innovation}

The literature on industrial districts highlights the way that the district model fosters the innovative ability of firms and helps promote the adoption of innovations ${ }^{1}$. PIORE and SABLE (1984) remark that continuous innovation is an intrinsic characteristic of industrial districts and a vital condition for their continuous change and growth. BELLANDI $(1989 ; 1996)$ remarks that in industrial districts there is a "diffuse innovation capacity", an ability to learn from experience (learning by doing) and to innovate from it, which conceptually substitutes the R\&D department of the Fordist large firm (learning by $R \& D)$. GAROFOLI (1989, p.81) highlights that technological and organizational innovation in industrial districts takes "the connotations of a continuous process, with accumulation and interdependence of the effects from a large number of technological changes, each small in its individual basis; therefore, the connotations of an incremental innovative process (à la Rosenberg), rather than through big steps (à la Schumpeter)", although with the special feature that they are not bound to a single firm but rather tend to diffuse inside the LPS at great speed by means of informal mechanisms. ASHEIM (1994) points out that the "industrial atmosphere" can support the processes of imitation, adaptation and diffusion of innovation in industrial districts; and that agglomeration economies support incremental innovations through informal learning-by-doing and learning-by-using mechanisms that are primarily based on tacit knowledge. 
To understand how the innovation process takes place in an industrial district there is a need to emphasize the dual nature of knowledge regarding its transmission: contextual and codified. Contextual knowledge is closely related to the activity of a location, and grows at the same time as its spatial, temporal and social context. An important share of this knowledge is "tacit knowledge" which is difficult to transmit and reproduce outside of its original cultural context (BECATTINI, 2001; GERTLER, 2003; LAWSON and LORENZ, 2003). Codified knowledge mostly refers to scientific and technical knowledge compiled in codes that can be transmitted and learned by means of the usual mechanisms of communication and formal education, and does not need the experience of other people or a precise context.

Regarding this distinction, BECATTINI (2001) divides the learning process into four phases: socialization of contextual knowledge; decontextualisation and codification of the experience acquired in the location; re-elaboration of knowledge; and reabsorption of codified knowledge by the specific processes of the production of goods. This sequence produces a "cognitive spiral" that enhances continuous feedback from local knowledge, tradable goods produced, local agents and the local environment as a whole. From this conceptualization of the learning process, BECATTINI (2001) drew three conclusions: (1) "Empirical knowledge" becomes as important for production as scientific knowledge; (2) Contextual knowledge should be codified in some way to influence local processes; (3) Codified knowledge needs to be contextualized and combined with contextual knowledge to affect the production and innovation processes.

Empirical research of the links between industrial districts and innovation is one of the least common themes in the literature on industrial districts. Nevertheless, some scholars have contributed important research to the issue. BRUSCO (1975) finds that small metal-mechanical engineering firms around Bergamo have similar levels of 
technology to similar large firms, which contradicts the theory that technological innovation originates exclusively from internal investment. RUSSO (1996) showed that the high rates of technical progress in the ceramic district of Sassuolo can not be explained by $R \& D$ activities performed in individual firms but rather by the links between the users and producers of machinery in the ceramic industry. MOLINA (2002) finds that knowledge spillovers are important for the innovative dynamic in the Spanish ceramic district of Castellón. CAINELLI and DE LISO (2003) find that the change in added value for innovative and non-innovative firms in industrial districts is higher than for firms outside districts. MUSCIO (2006) finds that innovation in industrial districts is related to the cooperation between firms and the local division of labour while innovation in non-district firms is more related to internal and external R\&D activities.

However, there has been little endeavour to find out whether industrial districts are more or less innovative than other LPS. Very little has been done to measure the differential performance of industrial districts regarding innovation or to model the determinants of this differential, which we consider to be a key issue in a context where innovation (and not cost) is increasingly more fundamental for the competitiveness of localities and firms. In other words, is there an I-district effect and if so, what causes it?

\subsection{Theoretical determinants of the district effect}

The term "district effect" was coined by SIGNORINI (1994) to explain the higher rates of efficiency of firms located in industrial districts. DEI OTTATI (2006, p.74) defines the "district effect" as the "collection of competitive advantages derived from a strongly related collection of economies external to the individual firms although internal to the district”. 
Following MARSHALL (1890), the performance of firms in industrial districts is related to external economies, which is the result of:

1. A trained, specialized and flexible labour force: workers are more specialised and skilled in the local industry and in the different stages of the production process.

2. Specialized suppliers in all phases of the production chain: the spatial concentration permits the existence of specialized (and differentiated) firms at all stages of the production process, each forced to innovate in order to survive, reinforcing at the same time both integration and the links between them.

3. Knowledge spillover effects: the diffuse industrial culture, made up of a set of intangible elements pertaining to the LPS as a whole (entrepreneurship, cooperative spirit, technical know-how, knowledge socialisation) which Marshall referred to as an "industrial atmosphere". This allows knowledge to flow and allows firms in the district to benefit from higher rates of innovation and productivity.

MARSHALL $(1890 ; 1919)$ exposes other sources of local advantages related to the characteristics of the city, such as the size and income of the local market or the existence of other local specializations which can absorb the effects of external shocks affecting the district's specialization. Regional economics theories group these factors under the heading of "agglomeration economies", where the "localization economies" are basically the Marshallian district economies and "urbanization economies" describe the effects of the size of the local market and the effects of cultural and productive diversity (not only as a shock-absorber but also as an element that fosters the production of new knowledge).

Empirical research of the "district effect" has taken two approaches: parametric and non-parametric. The parametric approach is based on the econometric estimations of an economic function such that the parameters can provide information about the 
existence of the district effect. SIGNORINI (1994) uses this approach on a production function, obtaining evidence of the existence of a district effect on productivity, profitability, vertical integration and finance. FABIANI et al. (2000) find evidence that productive inefficiency is lower for firms located in industrial districts. GOLA and MORI (2000) and BRONZINI (2000) find evidence of the existence of a district effect in terms of export performance. COSTA and VILADECANS (1999) also find evidence regarding the characteristics of industrial districts and their positive influence on the international competitiveness of Spanish LPS.

The non-parametric approach used by HERNÁNDEZ and SOLER (2003) departs from the concept of Efficient Production Frontier and Data Envelopment Analysis (DEA) to obtain the inefficiency of each firm as the difference between its actual output and the maximum feasible output that can be obtained from the inputs used by the firm. Their findings for Valencia confirm the existence of a district effect for the firms located in industrial districts.

\section{FIRST EVIDENCE OF THE I-DISTRICT EFFECT}

\subsection{Measurement of innovation}

The measurement of innovation is a widely discussed topic in the literature and there is no agreement as to which indicator is the most appropriate (GRILCHES, 1990; ACS et al., 1992). Usually, innovation indicators are divided into "input indicators" (R\&D expenditure or jobs) and "output indicators" (patents, new product announcements). The main inconvenience of the former is that they fail to take into account activities related to contextual knowledge, which are more important in smaller firms, underestimating its 
innovative capacity. On the other hand, patents and new product announcements represent the outcome of the innovation process. As long as granted patents imply novelty and utility, and also an economic expenditure for the applicant, it is supposed that patented innovation is of economic value (GRILICHES, 1990). Furthermore, patent documents contain highly useful data such as the applicant's address, name, date and technological classification. For these reasons, patent indicators are the most widely employed indicators of innovation (KHAN and DERNIS, 2006) ${ }^{2}$. Therefore, we will use patents as our innovation indicator, which offers the additional advantage of being able to discuss our results regarding the most extended empirical line.

In order to avoid yearly fluctuations and taking into account the lags in the outcome of innovation processes, the common practice is to consider data on innovation in periods of 4-5 years (GRILICHES, 1992). We will focus on the data for the 20012006 period (both inclusive) ${ }^{3}$. Patent data is not restricted to a single register as is the usual practice but rather covers several sources to produce more precise counts: the Spanish Patent and Trade Mark Office (OEPM), the European Patent Office (EPO), the United States Patent and Trademark Office (USPTO) and the World Intellectual Property Organization (WIPO), and covers applications with at least one applicant with an address in Spain per year of application ${ }^{4}$. In treating the data, we avoided doublecounting (patents first applied for at the Spanish office and then extended by means of the European or World treaty, or vice-versa). The final database covers 22,500 documents for the whole 2001-2006 period.

\subsection{Typology of local production systems in Spain}


The territorial units are the 806 local labour markets in Spain (BOIX and GALLETTO, 2008) identified using the Italian SFORZI - ISTAT (2006) methodology, which is also very close to the English Travel-To-Work Areas (TTWA). The algorithm departs from the municipalities $(8,100$ in Spain) and uses data on jobs, resident employees and travelto-work commuting coming from the national Censuses to form the market areas. Local labour markets contain the area where the population lives and works, becoming a community of firms and people that can be identified as a local production system (DE PROPRIS 2005). Seven types of LPS are identified as shown in Table 1 and Figure 1:

Three types of manufacturing systems:

1. 205 Marshallian industrial districts, identified by BOIX and GALLETTO (2008) using the Italian SFORZI - ISTAT (2006) methodology. The industrial districts are LPS specialized in manufacturing and basically composed of SME (Table 1).

2. 66 manufacturing LPS of large firms, obtained from the procedure for the identification of industrial districts as those manufacturing systems which are specialized in large firms.

3. Other manufacturing LPS. There are 61 LPS obtained as a residual since they specialized in manufacturing although they are not classified as industrial districts or manufacturing LPS of large firms ${ }^{5}$.

We classify service LPS as those which, in the first stage of the SFORZI ISTAT algorithm, are specialized in services (Consumer services; Business services; Traditional services; and Social services). Two types of service LPS are differentiated in terms of innovation:

4. LPS specialized in services that belong to large metropolitan areas. BOIX (2006) identified five metropolitan areas in Spain of over 1,000,000 people (Madrid, Barcelona, Valencia, Seville and Bilbao) and found that their behaviour regarding 
innovation was quite different from that of other metropolitan areas. However, most of the LPS belonging to these metropolitan areas are in fact industrial districts and in the case of Valencia, the core LPS is classified as an industrial district. This reduces our category to only four central LPS: Madrid, Barcelona, Seville and Bilbao.

5. The other LPS specialized in services are a total of 102 LPS.

And finally, another two categories come from the first stage of the SFORZI ISTAT algorithm:

6. 333 LPS specialized in Primary (Agriculture, fishing, etc.) and Extractive activities.

7. 35 LPS specialized in Construction.

[INSERT TABLE 1]

[INSERT FIGURE 1]

3.3. First evidence of the I-district effect

The comparison of the maps of LPS by typology and innovations per million employees (Figures 1 and 2) show the high concentration of highly innovative LPS in the northeast of the country matching up with the concentration of industrial districts and manufacturing LPS of large firms. The territorial distribution of innovations and innovative intensity in Spain shows four stylized results:

1. Marshallian industrial districts and the core of the largest metropolitan areas are determinant for the innovative capacity of the country (Table 2). The four cores specialized in services in the largest metropolitan areas (28\% of the employment) 
generate $35 \%$ of Spanish innovations and a ratio of 288 innovations per employee, which is $25 \%$ above the national mean (230 innovations per employee). Marshallian industrial districts (21\% of the national employment) generate $30.6 \%$ of Spanish innovations and a ratio of 337 innovations per employee, $47 \%$ above the national average, being the most innovative LPS in Spain. Furthermore, $57.1 \%$ of industrial districts have an innovative intensity above the national mean and only 20 districts have no innovative activity in this period (Table 3 ).

2. Manufacturing LPS of large firms (10.9\% of employment) account for $12.1 \%$ of innovations. The innovative intensity is 256 patents per million employees a year, which is $11 \%$ above the national average but $32 \%$ below the industrial districts (Table 2). The sum of metropolitan areas, industrial districts and manufacturing LPS of large firms is $78 \%$ of total innovations in Spain and tends to be spatially concentrated, as shown in Figure 1 and Figure 2.

3. The remaining LPS account for $22 \%$ of innovations generated in Spain and their innovative intensity is below the national average. The remaining manufacturing LPS account for only $0.6 \%$ of national innovations and their innovative intensity is $24 \%$ below the national average. Service LPS which do not pertain to a large metropolitan area have $16 \%$ of innovations and the innovative intensity is $36 \%$ below the national average. LPS specialized in Construction (2.2\% of employment) generate $1.1 \%$ of total innovations with an innovative intensity that is $53 \%$ below the national average. Despite accounting for $41 \%$ of total LPS, those specialized in Primary and Extractive activities are the less innovative units with only $4.7 \%$ of total innovations, an innovative intensity $62 \%$ below the national average and $64 \%$ of the LPS that do not have any innovation (Tables 2 and 3). 
4. The results are robust to different time periods and indicators. In the previous periods, 1991-1995 and 1996-2001, the innovative intensity of industrial districts was $33 \%$ and $35 \%$ above the national average. Regarding the sensitivity of the indicator of innovation (patents) we tested whether the results are maintained with other two indicators that are available on a microdata level covering the same period: (1) industrial designs and models from the databases of the Spanish Patent and Trade Mark Office (OEPM), which is another indicator of output innovation; (2) and grants and loans provided by the Centre for the Development of Industrial Technology (CDTI), which can be interpreted as an input indicator (demand for public loans to innovate). In the three cases, industrial districts show the most important differential effect in relation to the Spanish average, clearly above that of large metropolitan areas and manufacturing LPS of large firms. Furthermore, the choice of patent indicators seems to be the most conservative option since the differentials are much larger in terms of designs and CDTI loans (Figure 3).

[INSERT FIGURE 2]

[INSERT TABLE 2]

[INSERT TABLE 3]

[INSERT FIGURE 3]

4. MODELLING THE DETERMINANTS OF THE I-DISTRICT EFFECT 


\subsection{Empirical model}

To test the existence of a district effect on innovation (I-district effect) and model its determinants, we need to relate this effect with some model of innovation. The most common specification in the literature is the knowledge production function introduced by GRILICHES (1979) and implemented by PAKES and GRILICHES (1984) ${ }^{6}$. This function relates innovation to $R \& D$ inputs. We modify the production function to also take into account other factors influencing innovative activity, such as in our case, external economies. Thus, the knowledge production function can be specified as:

$$
I_{j}=\gamma R_{j}^{\beta} Z_{j}^{\delta} \varepsilon
$$

where $I$ stands for a measure of knowledge creation (innovation) in an LPS $j, R$ is a measure of $R \& D$ activities, $Z$ is a vector that collects other variables affecting innovation (e.g. external economies), $\varepsilon$ is a nuisance, and $\gamma, \beta$ and $\delta$ are parameters.

An important issue is whether the district effect should be measured regarding the total number of innovations in an LPS or its relative intensity per capita. Most specifications of the empirical innovation function focus on the absolute number of innovations and after JAFFE (1989) it is common practice to include a variable of scale (e.g. population) to take into account the fact that the number of innovations is directly related to the size of the LPS. However, for the measurement of the district effect the relevant question is whether there are significant differentials in innovative intensity between the industrial districts and other LPS ${ }^{7}$. Thus, the output and the input factors are divided by the total number of employees in the LPS: 


$$
i_{j}=\gamma r_{j}^{\beta} Z_{j}^{\delta} \varepsilon
$$

where $i$ is the average innovation per worker and $r$ is the average $\mathrm{R} \& \mathrm{D}$ per worker in the LPS. The variables included in $Z$ can also be normalized by size if necessary. Taking logarithms, we transform the production function into a simple loglinear expression:

$$
\log i_{j}=\gamma+\beta \log r_{j}+\delta \log Z_{j}+\varepsilon_{j}
$$

We can also consider that the sources of innovation are related to idiosyncratic effects associated to each typology of LPS so that $\delta^{*}=f\left(Z_{j}\right)$, and the equation can be specified as a fixed effects model:

$$
\log i_{j}=\gamma+\beta \log r_{j}+\delta^{*}+\varepsilon_{j}
$$

\subsection{Dependent variable}

The dependent variable is the innovative intensity output (patents per employee) in LPS, expressed as an annual average per employee and using 2001 as the base year for employment.

\subsection{Explanatory variables}

Explanatory variables use 2001 data to reinforce causality and avoid simultaneity. Following the theoretical model these are expressed in logarithms and can be interpreted as elasticities. They are divided into three groups: 
1. Inputs: R\&D by LPS was assigned from regional data on the basis of the regional $R \& D$ intensity per employee in each institutional sector (business sector, universities and public administrations) and multiplied by the jobs per institutional sector in each LPS. Since university R\&D and jobs are concentrated in few LPS, which causes problems with the logarithms, the data was grouped into two categories: private and public $R \& D^{8}$.

2. Marshallian industrial district economies, grouped into four categories:

2.1. Rate of specialization or non diversity of the LPS, computed as a Hirschman-Herfindahl index of diversity on employment at 2 digits inside the LPS. Higher values indicate higher specialization (less diversity) of the economic structure:

$$
D I V_{j}=\sum_{j}\left(E_{i j} / E_{j}\right)^{2}
$$

2.2. Specialized pool of manufacturing workers: represented by the share of manufacturing employment in the LPS. We associate a larger average of manufacturing workers with more specialized skills in the local manufacturing productions.

2.3. Specialized suppliers in the LPS. Following DUMAIS et al. (2002), the presence of suppliers of sector $i$ in the LPS $j$ is:

$$
P_{i j}=\sum_{i \neq z} v_{i s} E_{z j}, \text { where } v_{i s}=v_{i s} / \sum v_{i s}
$$

where $v_{i s}$ is the share that sector $i$ demands from the other sectors, and $E_{z j}$ is the local employment in the sector. These shares are obtained from the Spanish Input-Output 
Tables (INE). The sum of these weighted sector employments are used to obtain a global indicator of the presence of suppliers in each LPS:

$$
S_{j}=\sum_{i} E_{i j} / \sum_{i} P_{i j}
$$

If $S_{j}$ is larger than one, employment in supplying sectors in LPS $j\left(E_{i j}\right)$ is larger than the weighted sum of employment in supplying sectors $\left(P_{i j}\right)$ so that the presence of suppliers is above the local requirements and indicates the existence of a powerful chain of suppliers.

2.4. Social organization of production, using as a proxy the social capital index developed by IVIE (PÉREZ et al., 2006). This index is only available by province and informs whether the province has a level of social capital above, equal or lower than the national average. We assign the value of the province to an LPS.

2.5. Average of SME in the LPS, to control which model of organization of production is related to differentials in the innovative intensity. In the MarshallBecattini framework, the district effect should be related to SME:

$$
S M E_{j}=\sum E_{S M E, j} / \sum E_{j}
$$

, where $E_{S M E}$ is the employment in SME.

3. Urbanization economies:

3.1. Total population in the LPS (from 2001 Census).

3.2. Density index, which interprets that a greater density of employment (E) over population $(\mathrm{N})$ is related to denser work-related networks, which generates higher 


\subsection{Econometric evidence of the I-district effect}

To test the existence of the I-district effect we estimated equations 3 and 4 as a panel of 806 LPS divided into seven typologies. The estimates were made in two stages: first, we tested for the existence of the I-district effect and its size and then modelled its determinants.

We estimated equation 4 by only introducing R\&D variables, which are the inputs in the model ${ }^{9}$. After subtracting the effect of inputs, we can assume that the remaining differential is due to the characteristics associated to each type of production system. Thus, we introduce a fixed effects estimation of the model. The seven fixed coefficients capture the different performances of each typology and inform whether they are statistically different from the average LPS. Since there are 206 LPS without innovations for which logarithms can not be computed, there is some doubt about a possible selection bias in the sample. On the one hand, it can be argued that LPS without innovations belong to rural and very sparsely populated areas and their inclusion could introduce more economic problems than the statistical problems solve. This is reasonable since these 206 systems only have $3.5 \%$ of the Spanish employment and $67 \%$ of this employment belongs to Primary and Extractive LPS (41\% of noninnovative LPS) (Table 3). On the other hand, if we suspect that any selection bias is introduced, we can treat the problem as a censured sample and introduce a Heckman 
estimate of the fixed-effects model. Since both arguments are reasonable, we decided to provide the estimates for the LPS that innovate (600 LPS) and the estimates of the Heckman model (806 LPS) ${ }^{10}$.

The results for input variables show that both private and public $R \& D$ are statistically significant. The coefficients range between 0.13 and 0.26 for private R\&D and between 0.08 and 0.19 for public R\&D (Table 4). The coefficients and statistical significance of the fixed effects provide robust evidence of the existence of an I-district effect that ranges between 0.44 and 0.48 in unitary deviations from the averaged group effect, and similar to the $47 \%$ deduced from Table 2 . The manufacturing LPS of large firms have a fixed effect of between 0.05 and 0.10 although it is not statistically significant. The other manufacturing LPS also show a high fixed effect (0.43 to 0.31). With the exception of the large metropolitan areas (the coefficient is positive but not statistically significant) all the other typologies show negative differential effects ranging from -0.18 for Other service LPS to -0.52 for Primary and Extractive activities.

\section{[INSERT TABLE 4]}

\subsection{Modelling the determinants of the I-district effect}

To model the determinants of fixed effects we introduced the vector of external economies $Z_{j}$ to equation 4 :

$$
\log i_{j}=\gamma+\beta \log r_{j}+\delta \log Z_{j}+\delta^{*}+\varepsilon_{j}
$$


Note that if $\delta$ and $\delta^{*}$ are correlated, as in fact we assumed, the value of the coefficients and the statistical significance of $\delta^{*}$ will drop when we include $Z_{j}$.

We estimate equation 10 by introducing first the determinants of the Marshallian economies and later the urbanization economies. The results introducing Marshallian economies (Table 5, estimates 2.1 to 2.3 ) show a reduction in the $R \& D$ coefficients (0.11 to 0.14 for private $R \& D$ and 0.12 to 0.17 for public $R \& D$ ). The variables introduced are statistically significant, with large coefficients and the expected sign for the global rate of specialization ( 0.12 to 0.25$)$, specialization in manufacturing ( 0.63 to $0.65)$, suppliers $(0.29$ to 0.33$)$ and social capital $(0.23$ to 0.27$)$. The percentage employment in SME is negative and statistically significant although the coefficient is not very high (0.12 to 0.13$)$. Given the very small average dimension of Spanish firms, this can be interpreted as a correlation with a minimum dimension to innovate ${ }^{11}$. Regarding fixed effects, most of the coefficients decrease to almost zero and become statistically non significant. The exception is manufacturing LPS of large firms, where the coefficient becomes negative and statistically significant.

Next, we include urbanization economies (Table 5, estimates 2.4 to 2.6). The Population coefficient is small (-0.03 to 0.05$)$, statistically non significant and negative except in the Heckman estimate, where the model detects that it is an important variable in the probability of having non-zero innovations. Density of jobs has a large coefficient (0.43 to 0.77$)$ and suggests the existence of general spillover processes related to innovative performance. As expected, this variable is correlated with social capital (which has a lower coefficient and loses statistical significance).

We also test for the existence of other effects, mainly related to knowledge and creativity. However, no solid evidence is found between patent intensity and other knowledge variables such as knowledge-intensive manufacturing, knowledge-intensive 
services, ICT, creative class, percentage of employees in R\&D sectors, and university graduates (Figure 4$)^{12}$.

The existence of spatial autocorrelation between LPS was tested on the basis of a spatial contiguity matrix and simultaneous spatial lag and error effects. Although some evidence of the existence of simultaneous spatial spillover processes is detected (the spatial lag is dominant), its inclusion does not significantly improve the model ${ }^{13}$.

[INSERT TABLE 5]

\section{[INSERT FIGURE 4]}

\section{CONCLUSIONS}

The objective of the research was to explore the existence of higher rates of innovative intensity in the Spanish Marshallian industrial districts in the form of a "district effect" (I-district effect) as well as its causes. Given the importance of innovation for competitiveness and the arguments that present industrial districts as a model of mature industries based on costs, the results we present, performed on the system of innovation of an entire country, throw some light on this issue. The differential effects are compared not only with the national mean but also with manufacturing LPS of large firms, large metropolitan areas, other manufacturing LPS, service LPS, agricultural LPS, and construction LPS . The main conclusions are:

1. There is robust evidence of the existence of an I-district effect. The Marshallian industrial districts generate $30 \%$ of Spanish patents and an innovative intensity (patents per employee) of $47 \%$ more than the national average and $31 \%$ more 
than the manufacturing LPS of large firms. The econometric estimates of a fixed effects model confirm the existence of a similar I-district effect set between $44 \%$ and $48 \%$ in deviations from the averaged group effect. The evidence of this effect is maintained for the previous periods and using other indicators such as designs or loans for innovation.

2. The existence of the I-district effect is related to Marshallian economies as specialization, the existence of a specialized pool of manufacturing workers, specialized suppliers and social capital. As a result of the very small size of firms in the country, systems where the average firm is larger tend to innovate slightly more. Urbanization economies show less impact on innovation and on the explanation of the I-district effect although an important impact of spillovers coming from dense work-related networks is detected. Regarding the variables related to the knowledge economy, only private and public $\mathrm{R} \& \mathrm{D}$, introduced as an input in the model, appear to be directly linked to innovation. No solid evidence is found for other knowledge variables such as university graduates, knowledge-intensive industries or ICT.

3. The cores of the largest metropolitan areas specialized in services generate $35 \%$ of Spanish innovations and a ratio of 288 innovations per employee, $25 \%$ above the national mean although below industrial districts. Marshallian industrial districts and the core of the large metropolitan areas are determinant of the country's innovative capacity.

These results suggest the need to strengthen the territorial scope of innovation policies and to intensify research of their determinants by not only taking into account the characteristics of the firm but also the forms of innovation and the characteristics of the territory in each time period. In the light of our results, in Spain the common strategies based on basic research and development only explain a part of the innovation process and other forms of innovation coexist and are clearly operating in specific 
territorial contexts. The industrial district is one of the most outstanding as its innovative performance is correlated to its specialization, the existence of suppliers, and social and business networks. The State Secretariat for Industry (Ministry of Industry) synthesized this in a set of market-oriented measures and laws (Trullén 2007), centred on the so called "Innovative Business Groups", which reconcile innovation policy with the characteristics of territory.

\section{ACKNOWLEDGEMENTS}

The authors wish to thank Giacomo Becattini and two anonymous referees for helpful comments. We also thank the Spanish Patent and Trade Mark Office (Ministry of Industry, Tourism and Trade), the Centre for the Development of Industrial Technology (CDTI) and the Spanish Institute of Statistics (INE) for providing most of the data used in this research.

\footnotetext{
1 A comparative review of the literature on territorial innovation models including industrial districts, clusters, milieux innovateurs, new industrial spaces, etc. can be found in MOULAERT and SEKIA (2003).

2 The use of patents as indicators of innovation can be influenced by the industrial specialization of the LPS and firm size distributions. GRILCHES (1990 and 1992) and KHAN and DERNIS (2006) provide further discussion on their advantages and limitations.

${ }^{3}$ Our complete patent database includes 70,000 documents from 1991 to 2006. Patent counts include "utility models", a figure granted by the OEPM which is similar to the patent although legal requirements are less strict and protection covers only ten years.
} 
Similar figures exist in Austria, Denmark, Finland, Germany, Greece, Italy, Japan, Poland and Portugal. Employment data comes from the 2001 Census of the Spanish Institute of Statistics (INE).

${ }^{4}$ Data treatment follows international standards: patents are located according to the first applicant with an address in Spain (inventor's address is not available for national patents); reference date is the oldest application data in any register because it is the closest to the invention date and does not introduce biases due to legal or procedural delays.

${ }^{5}$ These include those LPS with the characteristics of an industrial district that BOIX and GALLETTO (2008) excluded because the number of employees in the main specialization was lower than 250 employees (considered too small), and also some LPS where manufacturing as a whole is of the average size of a large firm but without any large firm in the main specialization.

${ }^{6}$ This framework facilitates to compare and discuss the results. The choice of the dependent variable (patents) was also related to comparability.

7 This follows the line of other research that has used relative indicators in the measurement of the district effect, e.g. productivity (SIGNORINI, 1994) or efficiency (HERNÁNDEZ and SOLER, 2003).

${ }^{8}$ R\&D and employment data are taken from the INE. It is also possible to use hierarchical multilevel models to avoid the assignation although the hypothesis introduced for the data generates other restrictions. We control the results by using additional data on R\&D\&i grants and loans provided by the Ministry of Industry (CDTI and PROFIT databases). 
${ }^{9}$ R\&D per employee in the initial year is conceived as exogenous in our model. Additional test of exogeneity proves that this variable is empirically exogenous in all the regressions.

${ }^{10}$ Additional controls of the functional form of the model and the relation between the dependent and explanatory variables were introduced. The log-linear specification without non-linearities proved to be the most suitable specification.

${ }^{11}$ In fact, in industrial districts the average firm size is larger than in most of the other non manufacturing systems.

${ }^{12}$ In Spain more dynamic environments such as industrial districts provide numerous job opportunities for young people so that the necessity of higher levels of education to get work is not perceived. This result should not be interpreted as a direct indicator of the impact of contextual knowledge on innovation although it suggests the importance of contextual knowledge mechanisms (learning-by-doing, on-the-job training, etc.) to make up for the lower levels of standard-educated people.

${ }^{13}$ When the data is pooled, the spatial lag $(\rho=0.14)$ is statistically significant although it does not improve the fit. When fixed effects and external economies are included, the lag decreases to $\rho=0.08$ and again the most parsimonious model is preferred. This weak evidence and Figure 2 suggest that the impacts of inter-LPS spillovers could be locally important in the East and North-East of Spain where industrial districts and Large Firm LPS are concentrated. 


\title{
REFERENCES
}

ACS, Z., AUDRESTCH, D. and FELDMAN, M. (1992) Real effects of academic research: comment, The American Economic Review 82, 363-7.

\begin{abstract}
ASHEIM, B.T. (1994) Industrial districts, inter-firm co-operation and endogenous technological development: The experience of developed countries, in Technological dynamism in industrial districts: An alternative approach to industrialization in developing countries? UNCTAD, United Nations, New York and Geneva, 91-142.
\end{abstract}

BAGNASCO, A. and TRIGILIA, C. (Eds) (1984) Società e politica nelle aree di piccola impresa: Il caso di Bassano. Arsenale Editrice, Venezia.

BECATTINI, G. (Ed) (1975) Lo sviluppo economico della Toscana. IRPET, Firenze.

BECATTINI, G. (1990) The industrial district as a socio-economic concept, in PIKE, F., BECATTINI, G., SENGENBERGER, W. (Eds) Industrial Districts and Inter-Firm Cooperation in Italy. International Institute of Labour Studies, Geneva, pp. 37-51.

BECATTINI, G. (2001): The caterpillar and the butterfly. An exemplary case of development in the Italy of the industrial districts. Felice Le Monnier, Firenze.

BELLANDI, M. (1989) Capacità Innovativa Diffusa e Sistemi Locali di Imprese, in Becattini, G. (Ed) Modelli Locali di Sviluppo. Il Mulino, Bologna. 
BELLANDI, M. (1996) Innovation and change in the Marshallian industrial districts, European Planning Studies, 4:3, 357-68.

BELLANDI, M. (2002) Italian industrial districts: An industrial economics interpretation, European Planning Studies, 10:4, 425-37.

BOIX, R. (2006) Las áreas metropolitanas en España, XXXII Reunión de Estudios Regionales. Ourense.

BOIX, R. and GALLETTO, V. (2008) Marshallian industrial districts in Spain, Scienze Regionali - Italian Journal of Regional Science (forthcoming 2008).

BRONZINI, R. (2000) Sistemi produttivi locali e commercio estero: un'analisi territoriale delle esportazioni italiane, in SIGNORINI, L. F. (Ed) (2000) Lo sviluppo locale. Un'indagine della Banca d'Italia sui distretti industriali. Meridiana Libri, Corigliano Calabro.

BRUSCO, S. (1975) Economie di scala e livello tecnologico nelle piccole imprese, in A. Graziani (Ed) Crisi e ristrutturazione nell'economia italiana. Einaudi, Torino, pp. 530-59.

BRUSCO, S. (1991) La genesi dell'idea di distretto industriale, in PYKE, F., BECATTINI, G. and SENGENBERGER, W. (Ed) Distretti industriali e cooperazione tra imprese in Italia. Studi e informazioni, Quaderni 34, pp. 51-66. 
CAINELLI, G. and DE LISO, N. (2005) Innovation in Industrial Districts: Evidence from Italy, Industry and Innovation 12:3, 383 - 98.

COSTA, M.T. and VILADECANS, E. (1999) The district effect and the competitiveness of manufacturing companies in local productive systems, Urban Studies 36:12, 2085-98.

DEI OTTATI, G. (2002) Social concertation and local development: The case of industrial districts, European Planning Studies 10:4, 449-66.

DEI OTTATI, G. (2006) El 'efecto distrito': algunos aspectos conceptuales de sus ventajas competitivas, Economía Industrial 359, 73-87.

DE PROPRIS, L. (2005) Mapping Local Production Systems in the UK: Methodology and Application, Regional Studies 39:2, 197-211.

DUMAIS, G., ELLISON, G. and GLAESER, E.L. (2002) Geographic concentration as a dynamic process, Review of Economics and Statistics 84:2, 533-55.

FABIANI S., PELlEGRINI G., ROMAGNANO E., SIGNORINI L.F. (2000) L'efficienza delle imprese nei distretti industriali italiani, in SIGNORINI, F. (Ed) Lo sviluppo locale. Un'indagine della Banca d'Italia sui distretti industriali. Meridiana Libri, Corigliano Calabro. 
GAROFOLI, G. (1989) Modelli Locali di Sviluppo: I Sistemi di Piccola Impresa, in Becattini, G. (Ed.) Modelli Locali di Sviluppo. Il Mulino, Bologna.

GERTLER, M.S. (2003) Tacit knowledge and the economic geography of context, or The undefinable tacitness of being (there), Journal of Economic Geography 3, 75-99.

GOLA, C. and MORI, A. (2000) Concentrazione spaziale della produzione e specializzazione internazionale dell'industria italiana, in SIGNORINI, F. (Ed) Lo sviluppo locale. Un'indagine della Banca d'Italia sui distretti industriali. Meridiana Libri, Corigliano Calabro.

GRILICHES, Z. (1979) Issues in assessing the contribution of research and development to productivity growth, Bell Journal of Economics 10:1, 92-116.

GRILICHES, Z. (1990) Patent statistics as economic indicators: a survey, Journal of Economic Literature XXVIII, 1661-707.

GRILICHES, Z. (1992) The search for R\&D spillovers, Scandinavian Journal of Economics 94, 29-47.

HARRISON, B (1992) Industrial districts: Old wine in new bottles, Regional Studies 26:5, 469-83.

HERNÁNDEZ, F. and SOLER, V. (2003) Cuantificación del 'efecto distrito’ a través de medidas no radiales de eficiencia técnica, Investigaciones Regionales 3, 25-40. 
ISTAT (2006) Distretti industriali e sistemi locali del lavoro 2001, Collana Censimenti. Roma.

JAFFE, A. (1989) Real effects of academic research, The American Economic Review 79:5, 957-70.

KHAN, M. and DERNIS , H. (2006) Global Overview of Innovative Activities from the Patent Indicators Perspective, OECD Science, Technology and Industry Working Papers 2006/3. OECD Publishing, Paris.

LAWSON, C. and LORENZ, E. (2003), Collective learning, tacit knowledge and regional innovative capacity, Regional Studies 33:4, 305-17.

LAZZERETTI, L. and STORAI, D. (2003) An ecology based interpretation of district 'complexification': the Prato district evolution from 1946 to 1993, in BELLUSSI, F., GOTTARDI, G. and RULLANI, E. The technological evolution of industrial districts. Kluwer Academic Publishers, Boston.

MARSHALL, A. (1890) Principles of economics. McMillan, London.

MARSHALL, A. (1919) Industry and trade. McMillan, London.

MOLINA, X. (2002) Industrial districts and innovation: the case of the Spanish ceramic tiles industry, Entrepreneurship \& Regional Development 14, 317-35. 
MOULAERT, F. and SEKIA, F. (2003): Territorial Innovation Models: A Critical Survey, Regional Studies 37:3, 289-302.

MUSCIO, A. (2006) Patterns of Innovation in Industrial Districts: An Empirical Analysis, Industry and Innovation 13:3, 291 - 312.

OKAMOTO, Y. (2001) The evolution of industrial districts and the role of community, Journal of International Economic Studies 15, 167-78.

PAKES, A. and GRILICHES, Z. (1984) Patents and R\&D at the Firm Level: A First Look, in GRILICHES (Ed.) $R \& D$, Patents and Productivity. University of Chicago Press, Chicago.

PÉREZ, F., MONTESINOS, V., SERRANO, L. y FERNÁNDEZ, J. (2005) La medición del capital social: Una aproximación económica. Fundación BBVA, Bilbao.

PIORE, M. and SABLE, C. (1984) The second industrial divide: possibilities for prosperity. Basic Books, New York.

RUSSO, M. (1996) Cambiamento tecnico e relazioni tra imprese. Rosenberg \& Sellier, Torino.

SENGENBERGER, W. and PYKE, F. (1992) Industrial districts and local economic regeneration: research and policy issues, in PYKE, F. and SENGENBERGER, W. (Eds) 
Industrial Districts and Local Economic Regeneration. International Institute of Labour Studies, Geneva, 3-29.

SFORZI, F. (1987) L'identificazione spaziale, in BECATTINI, G. (Ed.) Mercato e forze locali: il distretto industriale. Il Mulino. Bologna, pp. 143-67.

SIGNORINI, L.F. (1994) The price of Prato, or measuring the industrial district effect, Papers in Regional Science, 73: 4, 369-92.

TRULLÉN, J. (2007) La nueva política industrial española: innovación, economías externas and productividad, Economía Industrial 363, 17-31. 
Table 1. Typology of local production systems in Spain: synthesis of criteria

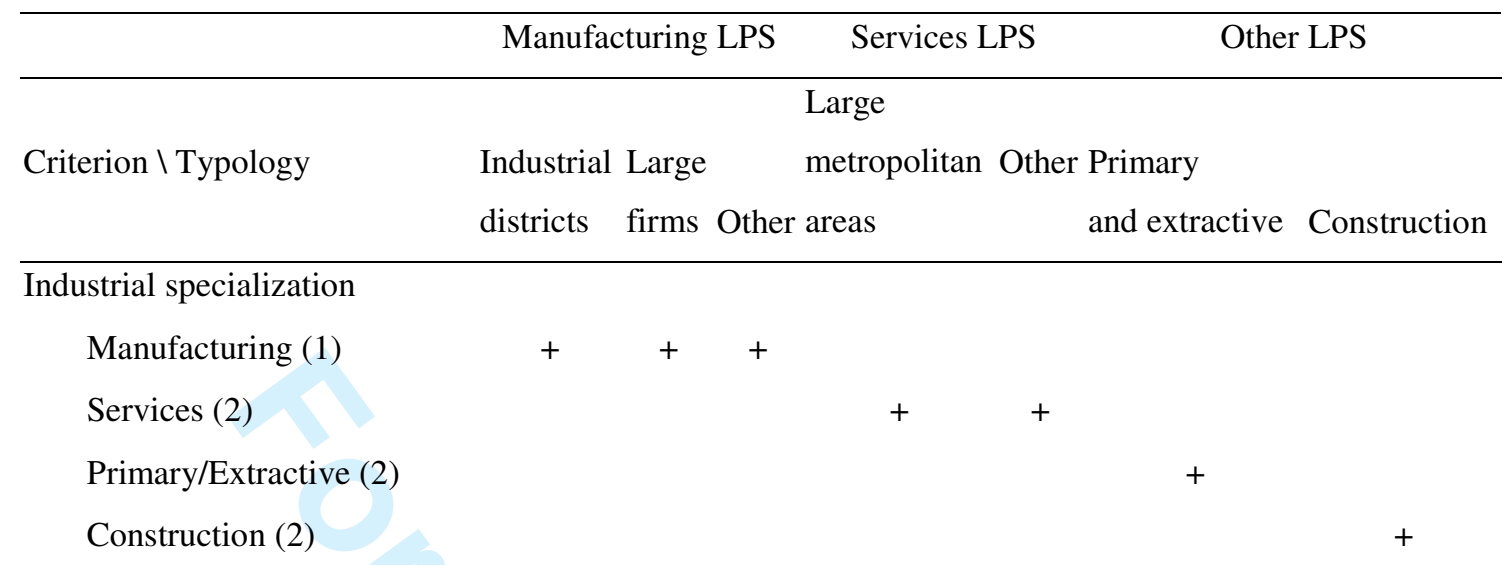

Firm size

LPS specialized in SME (3)

Main industry

specialized in SME (4)

Others

Above 250 employees

in the main industry

Above 1 million

inhabitants

$+$

(1) Location Quotient $\left(L Q 1_{L L M, N A C E}=\left(L_{L L M, N A C E} / L_{N A C E}\right) /\left(L_{L L M} / L\right)\right)$ above 1 in manufacturing and prevalence index $\left(P R 1_{L L M, N A C E}=\left[\left(L_{L L M, N A C E} / L_{N A C E}\right)-\left(L_{L L M} / L\right)\right] L_{N A C E}\right)$ is higher than those of Business services and Consumer services.

(2) For LPS non-specialized in manufacturing the specialization coincides with the largest LQ: Agricultural, Extractive, Construction, Business services, Consumer services, Social services, Traditional services.

(3) Largest LQ on firm size of the LPS corresponds to small or medium enterprises

(4) Percentage of SME in the main industry (2 digits) above 50\% 
Table 2. Distribution of innovation (patents) by Local Production System. 2001-2006

\begin{tabular}{|c|c|c|c|c|c|c|c|c|c|c|}
\hline \multirow[t]{3}{*}{ Type of LPS } & \multicolumn{2}{|c|}{$\begin{array}{l}\text { Local } \\
\text { production } \\
\text { systems }\end{array}$} & \multicolumn{2}{|c|}{$\begin{array}{l}\text { Employment } \\
\text { year } 2001 \\
\text { (thousands) }\end{array}$} & \multicolumn{3}{|c|}{$\begin{array}{c}\text { Patents } \\
\text { 2001-2006 }\end{array}$} & \multicolumn{3}{|c|}{$\begin{array}{c}\text { LPS where patents per } \\
\text { employee are above the } \\
\text { national average }\end{array}$} \\
\hline & \multirow[b]{2}{*}{$\mathrm{N}^{\mathrm{o}}$} & \multirow[b]{2}{*}{$\%$} & \multirow[b]{2}{*}{ Total } & \multirow[b]{2}{*}{$\%$} & \multicolumn{3}{|c|}{$\begin{array}{l}\text { Per million } \\
\text { employees }\end{array}$} & \multirow{2}{*}{\multicolumn{2}{|c|}{$\begin{array}{r}\% \\
\text { Total typology }\end{array}$}} & \multirow{2}{*}{$\begin{array}{r}\% \\
\text { total LPS }\end{array}$} \\
\hline & & & & & Total & $\%$ & /year & & & \\
\hline Primary and extractive activities & 333 & 41.3 & 1,994 & 12.2 & 1,048 & 4.7 & 88 & 41 & 12.3 & 5.1 \\
\hline Manufacturing & 332 & 41.2 & 5,317 & 32.6 & 9,764 & 43.3 & 306 & 169 & 50.9 & 21.0 \\
\hline Industrial districts & 205 & 25.4 & 3,419 & 20.9 & 6,908 & 30.6 & 337 & 117 & 57.1 & 14.5 \\
\hline LPS of large firms & 66 & 8.2 & 1,776 & 10.9 & 2,728 & 12.1 & 256 & 30 & 45.5 & 3.7 \\
\hline Other manufacturing LPS & 61 & 7.6 & 122 & 0.8 & 127 & 0.6 & 174 & 22 & 36.1 & 2.7 \\
\hline Construction & 35 & 4.3 & 364 & 2.2 & 238 & 1.1 & 109 & 6 & 17.1 & 0.7 \\
\hline Services & 106 & 13.2 & 8,654 & 53.0 & 11,502 & 51.0 & 222 & 28 & 26.4 & 3.5 \\
\hline Large metropolitan areas & 4 & 0.5 & 4,567 & 28.0 & 7,901 & 35.0 & 288 & 3 & 75.0 & 0.4 \\
\hline Other service LPS & 102 & 12.7 & 4,088 & 25.0 & 3,601 & 16.0 & 147 & 25 & 24.5 & 3.1 \\
\hline TOTAL & 806 & 100 & 16,330 & 100 & 22,552 & 100.00 & 230 & 244 & 30.3 & 30.3 \\
\hline
\end{tabular}


Table 3. Local Production Systems without innovations (patents). 2001-2006

\begin{tabular}{|c|c|c|c|c|c|c|c|c|}
\hline \multirow[b]{3}{*}{ Type of LPS } & \multicolumn{4}{|c|}{ Local production systems } & \multicolumn{4}{|c|}{ Employment year 2001} \\
\hline & & $\%$ & $\%$ non - & $\%$ & & $\%$ & $\%$ non - & $\%$ \\
\hline & Total & typology & innovative & total LPS & Total & typology & innovative & total LPS \\
\hline Primary and extractive & & & & & & & & \\
\hline activities & 132 & 39.6 & 64.1 & 16.3 & 379,657 & 19.0 & 67.2 & 2.3 \\
\hline Manufacturing & 52 & 15.7 & 25.2 & 6.4 & 136,891 & 2.6 & 24.2 & 0.8 \\
\hline Industrial districts & 20 & 9.8 & 9.7 & 2.5 & 72,982 & 2.1 & 12.9 & 0.4 \\
\hline LPS of large firms & 8 & 12.1 & 3.9 & 1,0 & 21,627 & 1.2 & 3.8 & 0.1 \\
\hline Other manufacturing LPS & 24 & 39.3 & 11.7 & 2.9 & 42,282 & 34.7 & 7.5 & 0.3 \\
\hline Construction & 8 & 22.9 & 3.9 & 1,0 & 17,764 & 4.9 & 3.1 & 0.1 \\
\hline Services & 14 & 13.2 & 6.8 & 1.7 & 31,009 & 0.4 & 5.5 & 0.2 \\
\hline Large metropolitan areas & 0 & 0.0 & 0.0 & 0.0 & 0 & 0.0 & 0.0 & 0.0 \\
\hline Other service LPS & 14 & 13.7 & 6.8 & 1.7 & 31,009 & 0.8 & 5.5 & 0.2 \\
\hline TOTAL & 206 & 25.6 & 100.0 & 25.6 & 565,321 & 3.5 & 100.0 & 3.5 \\
\hline
\end{tabular}

Source: Elaborated from Census 2001 (INE), OEPM, WIPO, USPTO and EPO. 
Table 4. Basic model and I-district effect

\begin{tabular}{|c|c|c|c|}
\hline & $\begin{array}{l}(1.1) \\
\text { OLS }\end{array}$ & $\begin{array}{r}(1.2) \\
\text { Fixed } \\
\text { effects }\end{array}$ & $\begin{array}{r}(1.3) \\
\text { Heckman } \\
\text { fixed effects }\end{array}$ \\
\hline Constant & $\begin{array}{l}0.3461 * * * \\
(0.000)\end{array}$ & $\begin{array}{l}5.4645 * \\
(0.095)\end{array}$ & $\begin{array}{l}5.1464 * * * \\
(0.000)\end{array}$ \\
\hline$R \& D$ firms & $\begin{array}{l}0.1304 * * * \\
(0.000)\end{array}$ & $\begin{array}{l}0.2362 \\
(0.040) * *\end{array}$ & $\begin{array}{l}0.2635 * * * \\
(0.000)\end{array}$ \\
\hline $\mathrm{R} \& \mathrm{D}$ public & $\begin{array}{l}0.0881 * * \\
(0.016)\end{array}$ & $\begin{array}{l}0.1418 \\
(0.057) *\end{array}$ & $\begin{array}{l}0.1902 * * * \\
(0.001)\end{array}$ \\
\hline Fixed Effects & & & \\
\hline Industrial districts & & $\begin{array}{l}0.4441 * * * \\
(0.000)\end{array}$ & $\begin{array}{l}0.4840 * * * \\
(0.000)\end{array}$ \\
\hline Manufacturing LPS of large firms & & $\begin{array}{l}0.0514 \\
(0.640)\end{array}$ & $\begin{array}{l}0.1039 \\
(0.344)\end{array}$ \\
\hline Other manufacturing LPS & & $\begin{array}{l}0.4379 * * * \\
(0.001)\end{array}$ & $\begin{array}{l}0.3167 * * \\
(0.016)\end{array}$ \\
\hline Large metropolitan areas & & $\begin{array}{l}0.0716 \\
(0.833)\end{array}$ & $\begin{array}{l}0.0994 \\
(0.768)\end{array}$ \\
\hline Other service sectors & & $\begin{array}{l}-0.2404^{* *} \\
(0.016)\end{array}$ & $\begin{array}{l}-0.1829 * \\
(0.068)\end{array}$ \\
\hline Construction & & $\begin{array}{l}-0.3387 * * \\
(0.018)\end{array}$ & $\begin{array}{l}-0.2989 * * \\
(0.036)\end{array}$ \\
\hline Primary activities & & $\begin{array}{l}-0.4259 * * * \\
(0.000)\end{array}$ & $\begin{array}{l}-0.5222 * * * \\
(0.000)\end{array}$ \\
\hline Fixed effects F-test & & $0.000 * * *$ & $0.000 * * *$ \\
\hline LR selection $($ lambda $=0)$ & 0.924 & $0.000 * * *$ & $0.000 * * *$ \\
\hline Condition number & 6.08 & 6.08 & 7.45 \\
\hline R2-ajd / Pseudo R2 & 0.126 & 0.282 & 0.297 \\
\hline $\log -\mathrm{L}$ & -755.85 & -692.70 & -681.46 \\
\hline Akaike & 1517.70 & 1403.39 & 1370.91 \\
\hline BIC & 1530.89 & 1442.97 & 1388.50 \\
\hline Number of obs & 600 & 600 & 806 \\
\hline
\end{tabular}

Notes: (a) Dependent variable = Patents per employee in the 2001-2006 period; (b) All variables are natural logarithms; (c) P-values are in parentheses and asterisks represent statistical significance at $1 \%(* * *), 5 \%(* *)$ and $10 \%(*)$; (d) Within group effect model estimates; (e) Fixed effects provided under the restriction that $\sum \alpha_{i}=0$, so that the dummy coefficients mean deviations from the averaged group effect (intercept); (f) Heckman adjusted coefficients; (g) Robust Huber-White estimators when slight problems of heteroskedasticiy, collinearity or outliers are detected. 
Table 5. Modelling the determinants of innovative intensity

\begin{tabular}{|c|c|c|c|c|c|c|}
\hline & \multicolumn{3}{|c|}{ District economies } & \multicolumn{3}{|c|}{ Urbanization economies } \\
\hline & $(2.1)$ & $(2.2)$ & $(2.3)$ & $(2.4)$ & $(2.5)$ & $(2.6)$ \\
\hline & OLS & Fixed & Heckman & OLS & Fixed & Heckman \\
\hline & & effects & Fixed effects & & effects & Fixed effects \\
\hline \multirow[t]{2}{*}{ Constant } & $3.8702 * * *$ & $4.0174 * * *$ & $3.2688 * * *$ & 4.5534 *** & $4.5179 * * *$ & $3.5021 * * *$ \\
\hline & $(0.000)$ & $(0.000)$ & $(0.000)$ & $(0.000)$ & $(0.000)$ & $(0.000)$ \\
\hline \multirow[t]{2}{*}{$\mathrm{R} \& \mathrm{D}$ firms } & $0.1166 * * *$ & $0.1415 * * *$ & $0.1484 * * *$ & $0.1033 * *$ & $0.1264 * * *$ & $0.1269 * * *$ \\
\hline & $(0.003)$ & $(0.000)$ & $(0.000)$ & $(0.008)$ & $(0.002)$ & $(0.005)$ \\
\hline \multirow[t]{2}{*}{ R\&D public } & $0.1431 * * *$ & $0.1251 * *$ & $0.1777 * * *$ & $0.1479 * *$ & $0.1284 * *$ & $0.1197 * *$ \\
\hline & $(0.003)$ & $(0.015)$ & $(0.001)$ & $(0.010)$ & $(0.027)$ & $(0.056)$ \\
\hline \multirow[t]{2}{*}{ Specialization } & $0.2517 * * *$ & $0.2536 * * *$ & 0.1264 & $0.1798 *$ & $0.1889 *$ & 0.1181 \\
\hline & $(0.006)$ & $(0.007)$ & $(0.195)$ & $(0.080)$ & $(0.071)$ & $(0.248)$ \\
\hline \multirow[t]{2}{*}{ Specialization in manufacturing } & $0.6509 * * *$ & $0.6346 * * *$ & $0.6590 * * *$ & $0.6465 * * *$ & $0.6408 * * *$ & $0.6951 * * *$ \\
\hline & $(0.000)$ & $(0.000)$ & $(0.000)$ & $(0.000)$ & $(0.000)$ & $(0.000)$ \\
\hline \multirow[t]{2}{*}{ Suppliers } & $0.3360 * *$ & $0.2941 * *$ & $0.2927 * *$ & $0.3174 * *$ & $0.2878 *$ & $0.3459 * *$ \\
\hline & $(0.016)$ & $(0.045)$ & $(0.045)$ & $(0.024)$ & $(0.055)$ & $(0.014)$ \\
\hline \multirow[t]{2}{*}{ Social capital } & $0.2742 * * *$ & $0.2307 * *$ & $0.2481 * * *$ & $0.1633 *$ & 0.1430 & 0.1402 \\
\hline & $(0.000)$ & $(0.003)$ & $(0.001)$ & $(0.083)$ & $(0.130)$ & $(0.128)$ \\
\hline \multirow[t]{2}{*}{ SMEs } & $-0.1213 * *$ & $-0.1394 * * *$ & $-0.1229 * *$ & $-0.1094 *$ & $-0.1298 * *$ & $-0.1064 *$ \\
\hline & $(0.034)$ & $(0.009)$ & $(0.022)$ & $(0.058)$ & $(0.016)$ & $(0.052)$ \\
\hline \multirow[t]{2}{*}{ Population } & & & & -0.0311 & -0.0263 & 0.0563 \\
\hline & & & & $(0.314)$ & $(0.452)$ & $(0.147)$ \\
\hline \multirow[t]{2}{*}{ Density of jobs } & & & & $0.5029 *$ & 0.4320 & $0.7729 *$ \\
\hline & & & & $(0.069)$ & $(0.136)$ & $(0.005)$ \\
\hline \multicolumn{7}{|l|}{ Fixed Effects } \\
\hline \multirow[t]{2}{*}{ Industrial districts } & & 0.0184 & 0.0557 & & -0.0007 & 0.0874 \\
\hline & & $(0.844)$ & $(0.543)$ & & $(0.994)$ & $(0.335)$ \\
\hline \multirow[t]{2}{*}{ Manufacturing LPS of large firms } & & $-0.2540 * *$ & $-0.2085 *$ & & $-0.2650 * *$ & $-0.1975 *$ \\
\hline & & $(0.023)$ & $(0.056)$ & & $(0.018)$ & $(0.063)$ \\
\hline \multirow[t]{2}{*}{ Other manufacturing LPS } & & 0.1547 & -0.0238 & & 0.1244 & 0.1054 \\
\hline & & $(0.218)$ & $(0.850)$ & & $(0.363)$ & $(0.418)$ \\
\hline \multirow[t]{2}{*}{ Large metropolitan areas } & & 0.2027 & 0.1671 & & 0.2783 & -0.2749 \\
\hline & & $(0.524)$ & $(0.590)$ & & $(0.405)$ & $(0.398)$ \\
\hline \multirow[t]{2}{*}{ Other service sectors } & & 0.0660 & 0.1680 & & 0.0486 & $0.1696 *$ \\
\hline & & $(0.530)$ & $(0.107)$ & & $(0.647)$ & $(0.096)$ \\
\hline \multirow[t]{2}{*}{ Construction } & & -0.0867 & 0.0037 & & -0.0953 & 0.1296 \\
\hline & & $(0.539)$ & $(0.979)$ & & $(0.502)$ & $(0.347)$ \\
\hline \multirow[t]{2}{*}{ Primary activities } & & -0.1011 & $-0.1620 *$ & & -0.0902 & -0.0195 \\
\hline & & $(0.259)$ & $(0.066)$ & & $(0.339)$ & $(0.828)$ \\
\hline Fixed effects F-test & & $0.0730 *$ & $0.0195 * *$ & & 0.112 & $0.074 *$ \\
\hline LR selection (lambda $=0$ ) & $0.000 * * *$ & $0.000 * * *$ & $0.000 * * *$ & $0.000 * * *$ & $0.000 * * *$ & $0.000 * * *$ \\
\hline Condition number & 26.40 & 26.40 & 30.72 & 50.90 & 50.90 & 60.00 \\
\hline R2-ajd / Pseudo R2 & $0 . .3774$ & 0.3760 & 0.4219 & 0.381 & 0.376 & 0.437 \\
\hline $\log -\mathrm{L}$ & -654.03 & -648.14 & -631.76 & -652.02 & -646.74 & -615.62 \\
\hline Akaike & 1324.06 & 1312.28 & 1281.53 & 1324.04 & 1313.48 & 1265.24 \\
\hline BIC & 1359.23 & 1347.46 & 1321.10 & 1368.01 & 1357.45 & 1339.99 \\
\hline Number of obs & 600 & 600 & 806 & 600 & 600 & 806 \\
\hline
\end{tabular}

Notes: (a) Dependent variable = Patents per employee employment in the 2001-2006 period; (b) All variables are natural logarithms ; (c) P-values are in parentheses and asterisks represent statistical significance at $1 \%(* * *), 5 \%(* *)$ and $10 \%(*)$; (d) Within group effect model estimates; (e) Fixed effects provided under the restriction that $\sum \alpha_{i}=0$, so that the dummy coefficients mean deviations from the averaged group effect (intercept); (f) Heckman adjusted coefficients; (g) Robust Huber-White estimators when slight problems of heteroskedasticiy, collinearity or outliers are detected. 
Figure 1. Typology of Local Production Systems in Spain

Source: Elaborated from Boix and Galletto (2008). 


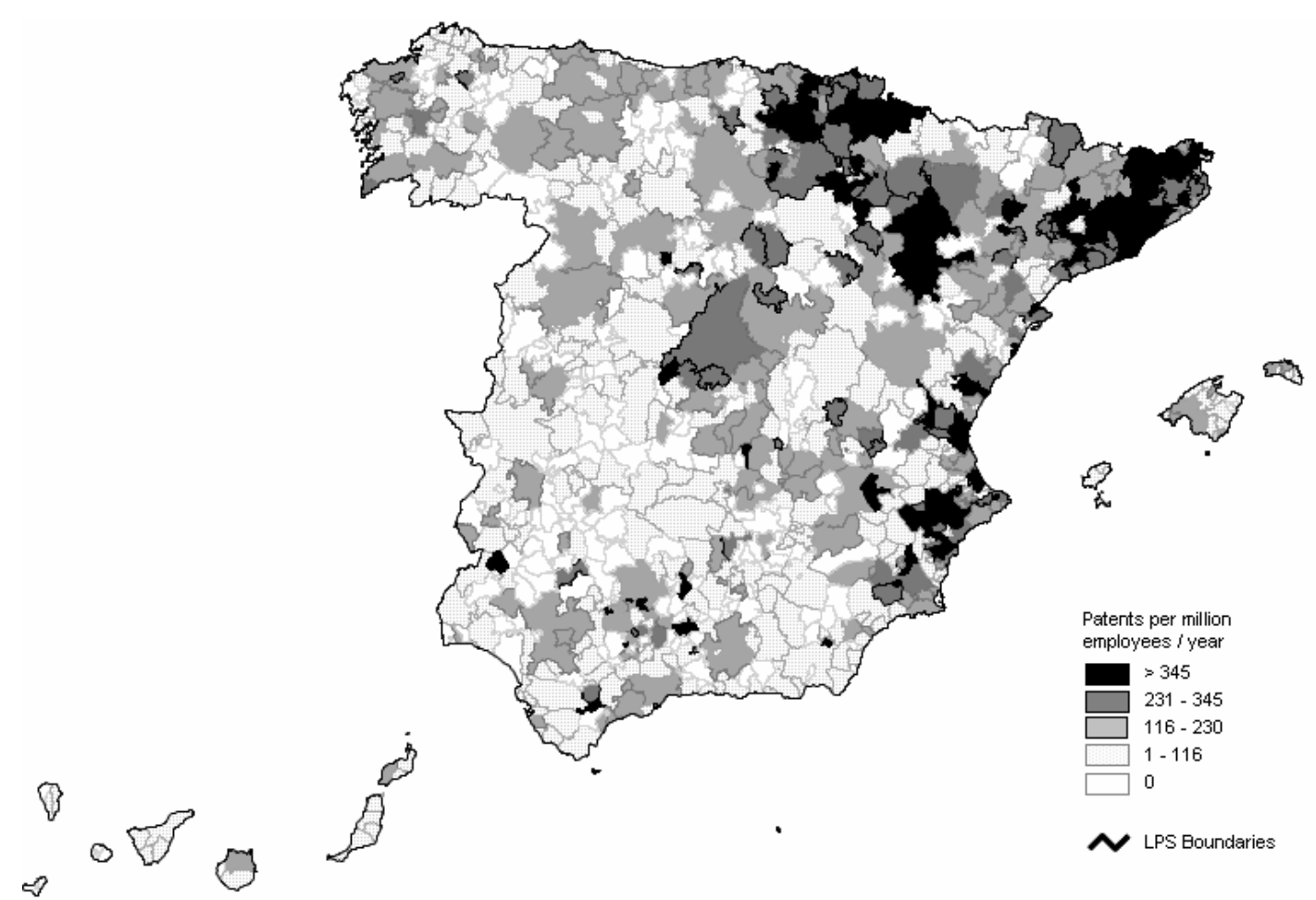

Figure 2. Patents per million employees. Annual average 2001 - 2006 Source: Elaborated from OEPM, EPO, WIPO, USPTO and Census 2001 (INE). 


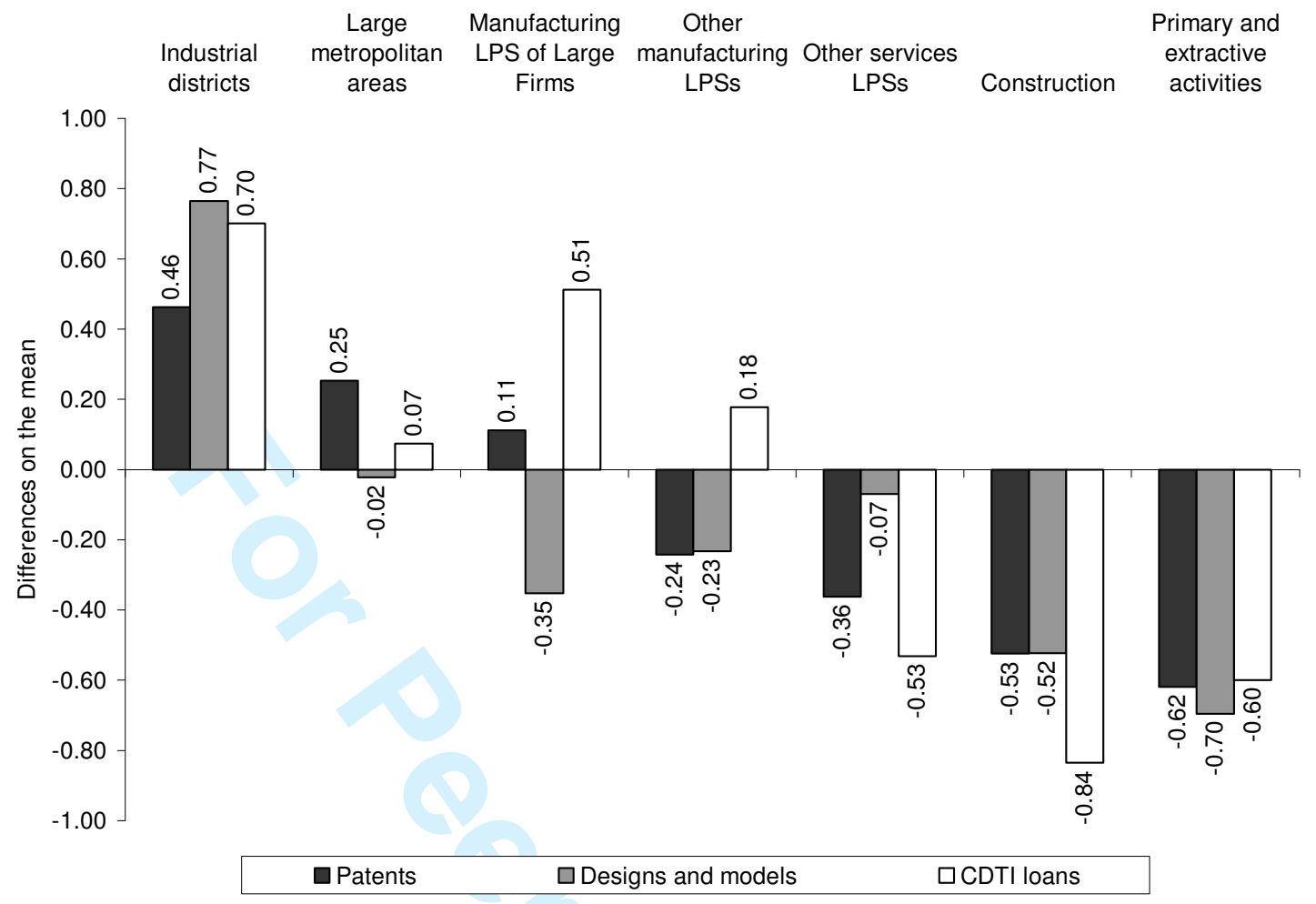

Figure 3. Innovative performance by typology of LPS and indicator. Innovations per million employees a year in differences to the mean of each indicator. 2001-2006 Source: Elaborated from OEPM, EPO, WIPO, USPTO, CDTI and Census 2001 (INE). 


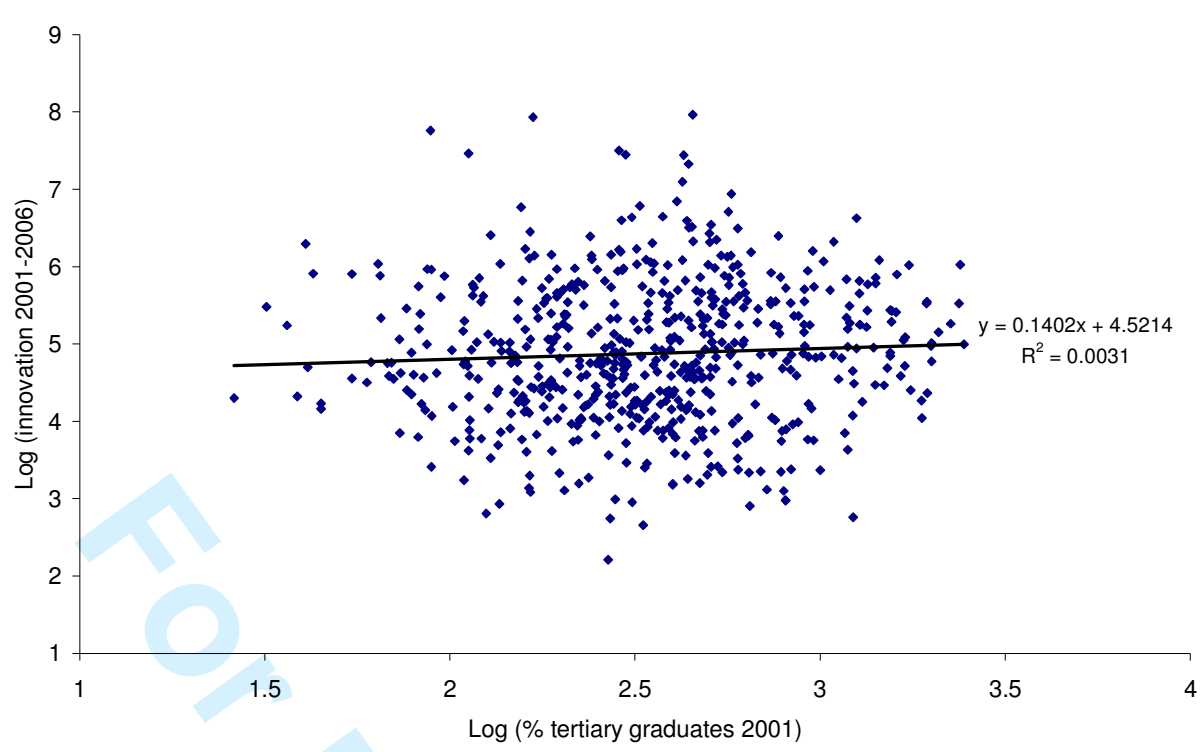

Figure 4. Innovation versus human capital (\% university graduated employees of total employees)

Source: Elaborated from OEPM, EPO, WIPO, USPTO, CDTI and Census 2001 (INE). 